\title{
Inoculation of Triatoma Virus (Dicistroviridae: Cripavirus) elicits a non-infective immune response in mice
}

\author{
Jailson F B Querido ${ }^{1}$, Jon Agirre ${ }^{2,3}$, Gerardo A Marti ${ }^{4}$, Diego M A Guérin ${ }^{2,3,5^{*}}$ and Marcelo Sousa Silva ${ }^{1 *}$
}

\begin{abstract}
Background: Dicistroviridae is a new family of small, non-enveloped, + ssRNA viruses pathogenic to both beneficial arthropods and insect pests. Little is known about the dicistrovirus replication mechanism or gene function, and any knowledge on these subjects comes mainly from comparisons with mammalian viruses from the Picornaviridae family. Due to its peculiar genome organization and characteristics of the per os viral transmission route, dicistroviruses make good candidates for use as biopesticides. Triatoma virus (TrV) is a pathogen of Triatoma infestans (Hemiptera: Reduviidae), one of the main vectors of the human trypanosomiasis disease called Chagas disease. TrV was postulated as a potential control agent against Chagas' vectors. Although there is no evidence that TrV nor other dicistroviruses replicate in species outside the Insecta class, the innocuousness of these viruses in humans and animals needs to be ascertained.
\end{abstract}

Methods: In this study, RT-PCR and ELISA were used to detect the infectivity of this virus in Mus musculus BALB/C mice. Results: In this study we have observed that there is no significant difference in the ratio $\lg G 2 \mathrm{a} / \mathrm{lgG} 1$ in sera from animals inoculated with TrV when compared with non-inoculated animals or mice inoculated only with non-infective TrV protein capsids.

Conclusions: We conclude that, under our experimental conditions, TrV is unable to replicate in mice. This study constitutes the first test to evaluate the infectivity of a dicistrovirus in a vertebrate animal model.

Keywords: Dicistroviridae, Triatoma virus, Chagas disease, triatomines, Trypanosoma cruzi, Mice immune response

\section{Background}

Dicistroviridae is a recently established family of small, non-enveloped viruses, containing a +ssRNA genome, and is classified under the order Picornavirales. This family contains 14 members classified within two genera, Cripavirus (type species Cricket paralysis virus, CrPV), and Aparavirus (type species Acute bee paralysis virus, ACP) [1,2]. A third genus has been recently proposed, Triatovirus (type species Triatoma virus, $\mathrm{TrV}$ ) [3]. All dicistroviruses are pathogenic to arthropods, although primarily to insects, representing significant threats to the health of beneficial arthropods such as acute bee paralysis virus, Black queen cell virus,

\footnotetext{
* Correspondence: diego.guerin@ehu.es; mssilva@ihmt.unl.pt

Unidad de Biofísica (UBF, CSIC-UPV/EHU), Barrio Sarriena S/N, 48940, Leioa, Bizkaia, Spain

${ }^{1}$ Centre for Malaria and Tropical Diseases - Instituto de Higiene e Medicina Tropical - Universidade Nova de Lisboa, Lisboa, Portugal

Full list of author information is available at the end of the article
}

Kashmir bee virus, which infects honeybees [4-6], and Taura syndrome virus, which is pathogenic to shrimps [7]. Two dicistrovirus members infect the model organism Drosophila melanogaster, Drosophila $C$ virus (DCV) and CrPV [8,9], and eight of them are pathogenic to insect pests, as it is the case with CrPV, which infects field crickets and the Olive Fruit Fly as well [7]. The aforementioned $\mathrm{CrPV}$ is quite ubiquitous and replicates in many other insect species spanning five orders [10]. Although dicistroviruses are believed to be arthropodspecific, antibodies against CrPV have been detected in sera from a pig, horse, and cattle [11]. Similarly, high levels of anti-TrV antibodies were detected in chickens used to feed a colony of TrV-infected insects, although the authors of this work concluded that the chickens were apparently refractory to the infection with $\operatorname{TrV}$ [12].

\section{Biomed Central}


Compared to other families of picornaviruses, little is known about dicistrovirus infection, replication mechanism or gene function. Most information about cellular infection and the replication cycle of dicistroviruses comes from studies on DCV, and by comparison with mammalian picornaviruses [1]. Many members of the Dicistroviridae family are considered novel candidates to be used as biopesticides [1,13-17].

$\mathrm{TrV}$ and Solenopsis invicta virus-1 are the two lone members of the Dicistroviridae family that infect insects of medical importance [1]. In fact, $\mathrm{TrV}$ is a natural enemy of Triatoma infestans (Hemiptera: Reduviidae), one of the main vectors of the trypanosomiasis disease called Chagas disease, a severe human illness most prevalent in almost all Latin American countries $[18,19]$. To date, $\operatorname{TrV}$ is the only entomopathogenic virus found in triatomines [20]. The viral particles are spherical, with a diameter of $30 \mathrm{~nm} \mathrm{[21],} \mathrm{and} \mathrm{consist} \mathrm{of} \mathrm{a} \mathrm{non-}$ enveloped capsid that encloses a $9010 \mathrm{nt}$ long viral genome [22]. The capsid contains four structural proteins VP1 (29.7 kDa), VP2 (28.4 kDa), VP3 (31.8 kDa) and a minor one VP0 $(37.3 \mathrm{kDa})$. In addition to these four structural proteins, this virus has a low molecular weight protein of $5.5 \mathrm{kDa}$ that appears to be detached from the capsid, lying at the particle interior and presumably in contact with the genome $[3,20,23]$. TrV can also infect natural populations of $T$. sordida and several experimental populations of triatomines as well [24]. Viral replication takes place in the midgut epithelium cells of triatomines, causing many deleterious sublethal effects in T. infestans and T. patagonica colonies, such as reduction of the longevity, increase of the developmental time, a decrease in both fecundity and fertility of eggs, and even a cumulative mortality higher than $97 \%$ [16,25-28].

As pointed out previously, the infectivity of $\mathrm{TrV}$ in vertebrates remains unclear. Therefore, in this work we studied the infectivity of $\mathrm{TrV}$ in mice (Mus musculus $\mathrm{BALB} / \mathrm{c}$ mice). Our results indicate that inoculations of both infective and non-infective $\mathrm{TrV}$ particles elicit the same immune response, and that this insect virus is unable to replicate in this animal model. Based on the bicistronic character of dicistrovirus genomes, it was speculated that these pathogens may not infect vertebrates, and this report constitutes important experimental evidence to support that hypothesis.

\section{Methods}

\section{Triatoma virus purification}

Virus purification was performed according to [3]. Dry feces obtained from infected insects were collected on Whatman filter papers and excised from them using a standard surgery scalpel until two g of material was collected. A buffer composed of $10 \mathrm{mM} \mathrm{NaCl}, 1 \mathrm{mM}$ $\mathrm{MgCl}_{2}$ and $200 \mathrm{mM}$ citric acid at $\mathrm{pH} 6$ (Lysis buffer) was added at a ratio of $100 \mathrm{~mL}$ per gram of dry material. PMSF (N 98.5\%, purchased from Sigma) thawed at $-20^{\circ} \mathrm{C}$ in isopropanol (Merck, GR for analysis) was added up to a final concentration of $1 \mathrm{mM}$. The mixture was homogenized for 5 min using a vortex mixer and then sonicated using a Sanyo MSE Soniprep 150 operating at $10 \mathrm{~s}$ ON/10 s OFF for 20 pulses. After centrifugation, the resulting pellet was resuspended in NMT buffer and then loaded on top of a $35 \mathrm{~mL}$ continuous $5 \%-30 \%$ sucrose gradient. The gradients were cooled in ice to avoid particle diffusion within them. The individual optical density of each aliquot was then measured at both $260 \mathrm{~nm}$ and $280 \mathrm{~nm}$. After plotting the absorbance profile, selected aliquots were loaded onto $12.5 \%$ polyacrylamide SDS-PAGE gels to check the purity of the samples. Following gradient fractionation, equivalent samples were pooled together and dialyzed overnight against $2 \mathrm{~L}$ of NMT buffer.

\section{Infection with Triatoma virus (TrV)}

Eight groups of female Mus musculus BALB/c mice (3 mice per group) between 5 and 8 weeks of age obtained from Instituto de Higiene e Medicina Tropical, Lisbon, Portugal, were used in the experimental infection with $\operatorname{TrV}$. Groups 1-5 were inoculated by intraperitoneal injection. Group 1 is the control group, which was inoculated only with PBS. Group 2 was inoculated with $3.0 \mu \mathrm{g}$ of empty $\mathrm{TrV}$ particles (capsids without genome, therefore non-infective) [3]. Group 3 was inoculated with 3.0 $\mu \mathrm{g}$ of $\mathrm{TrV}$, group 4 and group 5 with $0.3 \mu \mathrm{g}$ and $0.03 \mu \mathrm{g}$ of $\mathrm{TrV}$ respectively. Group 6 served as a negative control of per os inoculation, therefore it was inoculated only with $100 \mu \mathrm{l}$ of PBS delivered per os intraesophageally by using a $1 \mathrm{ml}$ tuberculin syringe and Gavage needle. Group 7 was inoculated with $3.0 \mu \mathrm{g}$ of empty TrV particles in $100 \mu \mathrm{l}$ of PBS, delivered per os intraesophageally by using a $1 \mathrm{ml}$ tuberculin syringe and Gavage needle. Group 8 was inoculated with $3.0 \mu \mathrm{g}$ of $\mathrm{TrV}$ in $100 \mu \mathrm{l}$ of PBS, delivered per os intraesophageally by using a $1 \mathrm{ml}$ tuberculin syringe and Gavage needle. After inoculation blood and feces samples were collected at different times (3, 7, 30 and 45 days). Forty-five days after inoculation, the animals were sacrificed.

All experiments on animals were conducted with prior approval from the Animal Welfare of General Management of Veterinarians (DGV - Portugal). All manipulations of mice satisfied the requirements of the Regulations of Experimental Animal from the Ethics Committee of IHMT/UNL-Portugal.

\section{Searching for $\operatorname{TrV}$ in blood and feces samples}

Blood samples from each mouse were collected into individual micro tubes containing $5 \mu \mathrm{l}$ of Heparin-Sodium (B. Braun, USA). The RNA was extracted according to 
the product manual supplied with the RNA isolation Kits, (Bioline, UK). RNA concentration was determined by measuring absorbance at $260 \mathrm{~nm}\left(\mathrm{Abs}_{260}\right)$ in a spectrophotometer (NanoDrop 1000, Thermo Scientific).

Feces samples were collected into micro tubes. For each group of mice we pooled the samples from all mice of this group. 1,2 mg of fecal samples resuspended in $200 \mu \mathrm{l}$ PBS were homogenized and centrifuged (5,000 rpm) for 10-15 minutes. $50 \mu \mathrm{l}$ of supernatant was then homogenized in TRIZOL reagent (Genbiotech, Argentina), and viral RNA$\operatorname{TrV}$ (vRNA) was purified according to the manufacturer's instructions. As a positive control of RNA extraction, we carried out the same procedure simultaneously with feces from triatomines infected with $\mathrm{TrV}$.

Purified vRNA $(0.724 \mu \mathrm{g})$ was used as a template for the positive control in the RT-PCR reaction. For the other RT-PCR, we used $5 \mu$ l of the samples resulting from the purification of the vRNA from blood and feces samples from the mice used in the infectivity experiment. The cDNA synthesis was performed according to the cDNA Synthesis Kit protocol (Bioline, UK). $5 \mu$ of the extraction product was used according to the OneStep RT-PCR protocol (QIAGEN; USA). TrV positive PCR reactions have a 832 bp product according to the protocol established in our previous work [26]. As a positive control of RT-PCR and RNA extraction from blood samples, we performed a PCR with two primer pairs from $\beta$-actin gene: $\beta$-actin sense: $5^{\prime}$ TGGAATC CTGTGGCATCCATGAAAC $3^{\prime}$ and $\beta$-actin anti-sense: $3^{\prime}$ TAAAACGCAGCTCAGTAACAGTCCG $5^{\prime}$, with an expected product of $348 \mathrm{bp}$ [29]. PCR products were visualized on $1.5 \%$ agarose gels for $\mathrm{TrV}$ and $2 \%$ agarose gel for $\beta$-actin, stained with ethidium bromide, and their sizes were determined by comparison against DNA markers, HyperLadder I (Bioline, UK) and HyperLadder IV (Bioline, UK) respectively.

\section{Production of mouse polyclonal antibodies to anti-TrV}

The serum used as a positive control in ELISA reactions were produced in female Mus musculus BALB/c mice between 5 and 8 weeks of age. The mice were inoculated (subcutaneous injection) with $100 \mu \mathrm{g}$ of empty $\mathrm{TrV}$ particles mixed with $100 \mu \mathrm{l}$ of Freund's complete adjuvant (Sigma-Aldrich, USA). Fifty days after the first inoculation, the animals were inoculated with $100 \mu \mathrm{g}$ of empty $\operatorname{TrV}$ particles mixed with $100 \mu \mathrm{l}$ of Freund's incomplete adjuvant (Sigma-Aldrich, USA). Ten days after the second inoculation, the animals were sacrificed and hyperimmune sera was obtained.

\section{Detection of anti-TrV IgGs antibodies by ELISA}

Naturally empty $\operatorname{TrV}$ particles were selected as antigens for their protein-only composition. These particles contain almost the same proteins as full particles, but at least $30 \%$ of its composition was integrated by 7 additional polypeptides that were determined to be misprocessed products from the cleavage of the structural protein precursor P1 [3]. Nevertheless, since both full and empty particle proteins share the same origin (P1), their antigenic properties remain essentially the same.

Three different concentrations of total proteins (50, 100 and $150 \mathrm{ng} /$ well) from the empty $\mathrm{TrV}$ particles were used to optimize the amount of antigen used in this reaction. We chose $100 \mathrm{ng} /$ well because with this value the amount of antigen is no longer the limiting reagent of the reaction. Total protein extract from empty TrV particles (in carbonate buffer $\mathrm{pH}$ 8.5) was adsorbed overnight at $4^{\circ} \mathrm{C}$ onto 96-well micro-plates (Nunc, Denmark) for use in indirect enzyme-linked immunosorbent assays (ELISA), using sera from inoculated mice. Subsequently, horseradish peroxidase, (HRP)-conjugated rat anti-mouse IgG (1:4000, SigmaAldrich, USA), rat anti-mouse IgG1 (500 ng/ml, AbD serotec, UK) or rat anti-mouse IgG2a (250 ng/ml, AbD serotec, UK) were used.

\section{Results}

\section{Absence of clinical infection signals}

Mice inoculated with $\mathrm{TrV}$ by intraperitoneal and per os route did not show any behavioral alteration or clinical signals of viral infection (e.g. leg paralysis, change in food intake rate, weight loss, decrease in motility and death), when compared with mice inoculated with empty $\operatorname{TrV}$ particles or saline solution (control groups), this is contrary to what happens in triatomines, where the insects inoculated with the virus show leg paralysis, delayed development and death $[16,22]$.

\section{Absence of TrV in blood and feces samples}

We analyzed all blood and feces samples from each group of animals at 0,3 and 45 days after inoculation. No RT-PCR products corresponding to $\mathrm{TrV}$ were detected from blood or feces samples of any of the groups of mice inoculated with $\mathrm{TrV}$ or mice inoculated with empty $\operatorname{TrV}$ particles (Figure 1). All blood samples showed PCR products corresponding to $\beta$-actin gene, with expected size (348 bp) (Figure 1-D).

\section{Detection anti-TrV IgGs antibodies by ELISA}

We performed ELISA to detect antibodies against $\operatorname{TrV}$ in sera extracted from inoculated mice. Total protein extract from empty $\operatorname{TrV}$ particles was used to detect the presence of anti- $\mathrm{TrV}$ antibodies in sera from noninoculated and inoculated BALB/c mice with TrV. We produced polyclonal antibodies to anti- $\mathrm{TrV}$ in mice in order to establish basal and positive signals in the ELISA. The cut-off value was defined using sera from non-inoculated mice, mean OD (optical density) + 3SD (standard deviation) at $490 \mathrm{~nm}$. We chose this weighting 


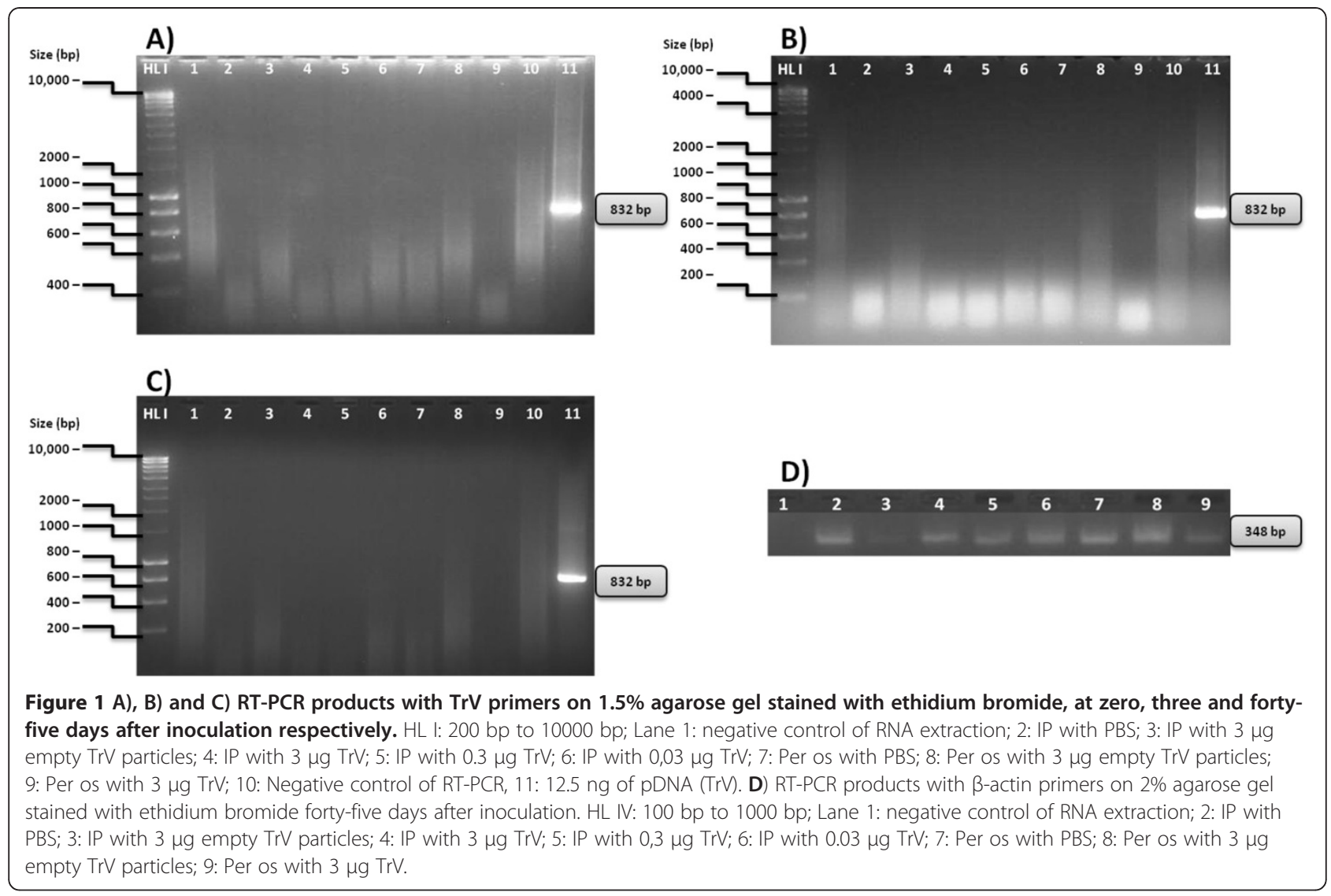

(3SD), because all sera from non-inoculated mice had OD values less than the cut-off value.

Forty-five days after intraperitoneal inoculations, all inoculated mice showed high levels of IgG anti-TrV antibodies when compared with sera from non-inoculated mice (Figure 2) or mice inoculated by per os route. Sera reactivity was directly proportional to the amount of antigen used in inoculation. However, there was no significant difference $(\mathrm{F}=0.0064$; $\mathrm{p}$-value $>0.05)$ between the reactivity of sera from mice inoculated with empty $\operatorname{TrV}$ particles to that of mice inoculated with the same amount of RNA-full $\mathrm{TrV}$ capsid (Additional file 1). All mice inoculated by the per os route presented levels of anti-TrV antibodies similar to mice inoculated only with PBS (Figure 2), indicating that per os inoculation with $\operatorname{TrV}$ produces little or no IgG antibody response in mice.

To define which subclasses of IgG anti-TrV were detected in sera from inoculated mice and in order to determine if $\mathrm{TrV}$ can replicate in mice, we measured the titers of IgG1 and IgG2a antibodies specific to $\operatorname{TrV}$ (Figure 2-B and $\mathrm{C}$ ). The results show that there is no significant difference in the IgG2a/IgG1 ratio between mice inoculated with $\mathrm{TrV}$, mice inoculated with empty $\mathrm{TrV}$ particles or non-inoculated mice (Figure 2-D).

\section{Discussion}

RT-PCR has been used to detect a variety of RNA viruses in different kinds of samples [9,30]. In this study, a RT-PCR assay has been developed to detect TrV from blood and feces samples from mice inoculated with TrV. Two specific pairs of primers for $\operatorname{TrV}$ were used and the 832 bp products expected for the $\mathrm{TrV}$-specific assay were produced only when TrV vRNA was present, indicating that this assay is highly specific for TrV.

In this PCR assay, PCR products were detected from samples with low concentrations of plasmid DNA (6.2 pg) encoding specific $\operatorname{TrV}$ sequences or $\operatorname{TrV}$ vRNA (2.5 ng) (data not shown). Therefore, if $\operatorname{TrV}$ were able to replicate in mice, their presence would be detected by RTPCR assay from blood and feces samples of inoculated mice. However, we were not able to detect any PCR products from blood or fecal samples of mice inoculated with $\mathrm{TrV}$. The absence of PCR products from these samples may indicate that $\operatorname{TrV}$ is unable to replicate in mice, this contrasts to what happens in triatomines, where this virus causes a high mortality rate, reduces fecundity and delays the development of infected insects $[16,25]$.

It has been postulated that the immune response triggered by viruses mainly activates the Th1 subset of $\mathrm{T}$ 

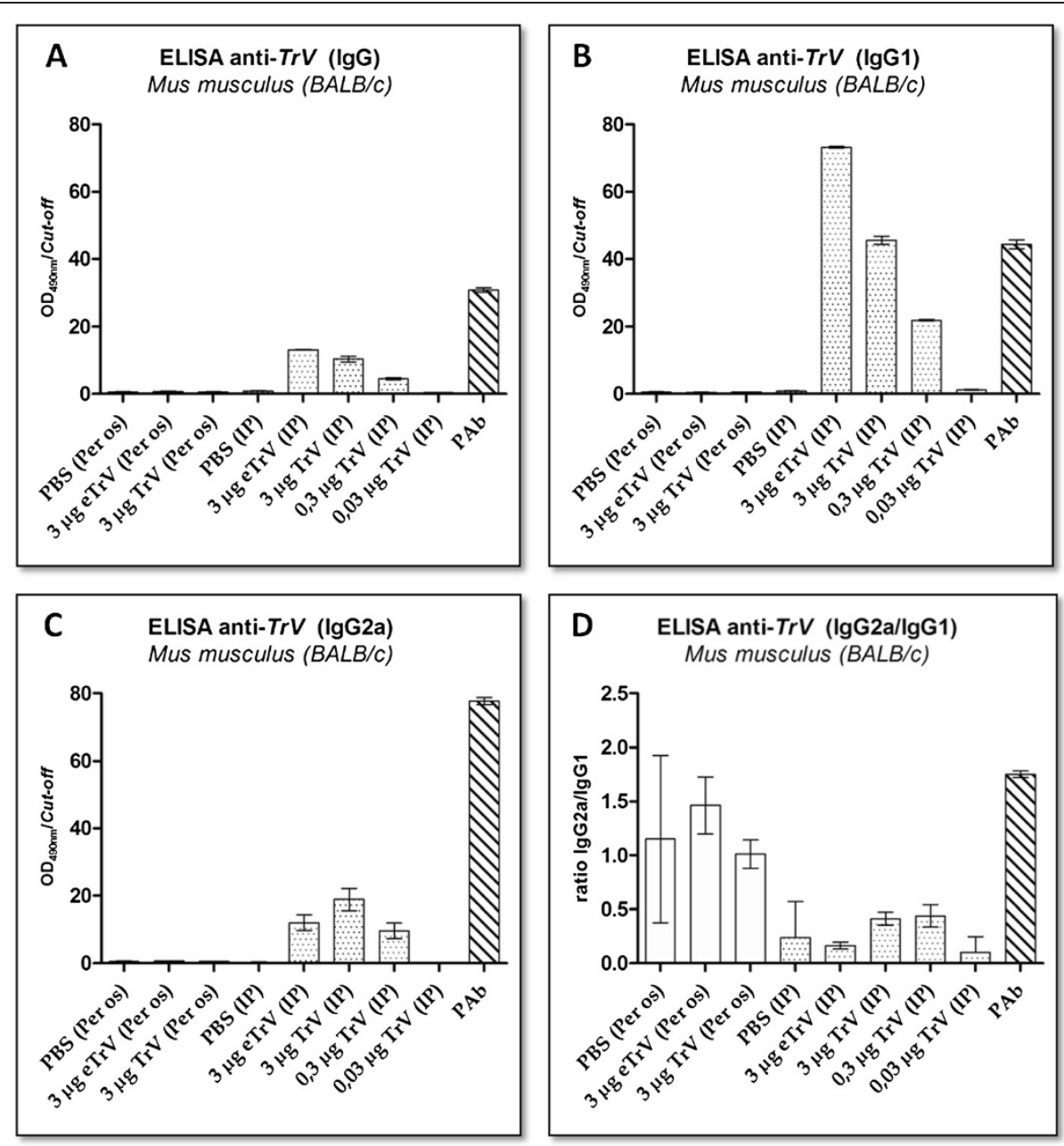

Figure 2 A) Levels of total IgG anti-TrV antibodies, B) Levels of total IgG1 anti-TrV antibodies, C) Levels of total IgG2a anti-TrV antibodies elicited in mice BALB/c inoculated with empty TrV particles (eTrV) and RNA-full TrV capsids (TrV); D) ratio IgG2a/lgG1 antibodies. Serum samples were taken on days 45 after injection. Each column represents the mean with standard deviation (SD) from the ratio of optical density $\left(\mathrm{OD}_{490} \mathrm{~nm}\right)$ and cut-off values (three mice per group). Cut-off value was defined as: mean $+3 \mathrm{SD}$. Abbreviations: IP: intraperitoneal route; PAb: Polyclonal antibodies.

helper cells and enhances the production of INF- $\gamma$, which is the reason many systemic viral infections in mice result in preferential increases in virus-specific IgG2a antibodies in serum [31,32]. This preferential class switch is dependent on viral replication and is attributed in part to virus-induced production of IFN- $\gamma$ [31]. In this study we observed that there is no significant difference in the ratio IgG2a/IgG1 in sera from animals inoculated with $\operatorname{TrV}$ when compared with non-inoculated animals or mice inoculated only with empty $\mathrm{TrV}$ particles. The results reported in this work support the idea that $\operatorname{TrV}$ is unable to replicate in vertebrates.

\section{Conclusions}

The results of the ELISA for anti-TrV together with the results of a TrV vRNA search by RT-PCR in blood and feces samples from mice inoculated with $\mathrm{TrV}$ indicate that this virus is not infective in mice, at least under the conditions explored in this study (infected by per os and intraperitoneal inoculations). The results reported in this work support the idea that $\operatorname{TrV}$ is a virus that only infects invertebrates.

To date, this study constitutes an important approach to evaluate the response of one vertebrate animal model to the experimental infection with a dicistrovirus. Future studies may lead to a better understanding of the TrV host range, and hopefully may also characterize the effect observed in humans and other vertebrates that are most likely to be exposed to dicistroviruses [10,22]. Certainly, to improve the current knowledge on $\mathrm{TrV}$, and in general, to gain information on the life cycle of any member of the Dicistroviridae family, will greatly help in establishing a proof of principle for employing dicistroviruses as biological agents to control insect pests. 


\section{Additional file}

Additional file 1: Statistical analysis (ANOVA, with Microsoft Excel ${ }^{\circledR}$ ) between the two groups of mice inoculated with the same concentration of RNA-full TrV capsids and empty TrV particles respectively $(3 \mathbf{\mu g})$. Considering that the data is normally distributed, this test helped to identify differences between mice inoculated with TrV and mice inoculated with the same amount of empty TrV particles. The null hypothesis $\left(\mathrm{H}_{0}\right)$ assumes that the means are statistically the same $\left(H_{0}: \mu_{1}=\mu_{2}\right)$, and the alternate hypothesis $\left(H_{A}\right)$ assumes that the means are statistically different $\left(H_{A}: \mu_{1} \neq \mu_{2}\right)$, at $95 \%$ confidence. Since the $F$ statistic is smaller than the critical value, we fail to reject the null hypothesis. Sum of squares (SS); Degrees of freedom (df); Mean square (MS).

\section{Competing interests}

The authors declare that they have no competing interests.

\section{Authors' contributions}

Conceived and designed the experiments: MSS, DMAG, GAM. Performed the experiments: JBQ, JA, MSS. Analysed the data: JBQ, GAM, MMAG, MSS. Wrote the paper: JBQ, DMAG, MSS. All authors have read and approved the final manuscript.

\section{Acknowledgments}

The authors are grateful to Rubén Sánchez-Eugenia and Sonia López (UBF) for their technical assistance in TrV purification, and to Dr. Carlos Robello from the Instituto Pasteur Montevideo for the gift of the complementary CDNA used as positive control in PCR assays. Thanks also to all personnel from the Department of Virology, Faculty of Veterinary Sciences, National University of La Plata. JA was supported by a UPV/EHU contract (UPV-IT-46107). GAM is a researcher of the CONICET, Argentina. DMAG was partially supported by grant SAIOTEK (Y-CRYSTAL), Gobierno Vasco (GV), and MICINN (BFU2007-62062), Spain. This work was partially supported by Acción Especial AE-2009-1-21, from the GV, Spain, and CYTED 209RT0364 action (RedTrV: www.redtrv.org), both granted to DMAG.

\section{Author details}

${ }^{1}$ Centre for Malaria and Tropical Diseases - Instituto de Higiene e Medicina Tropical - Universidade Nova de Lisboa, Lisboa, Portugal. ${ }^{2}$ Unidad de Biofísica (UBF, CSIC-UPV/EHU), Barrio Sarriena S/N, 48940, Leioa, Bizkaia, Spain. ${ }^{3} \mathrm{C}$ Fundación Biofísica Bizkaia, Barrio Sarriena S/N, 48940, Leioa, Bizkaia, Spain. ${ }^{4}$ Centro de Estudios Parasitológicos y de Vectores (CEPAVE-CCT-La PlataCONICET - UNLP) 2-584, 1900, La Plata, Argentina. ${ }^{5}$ Departamento de Bioquímica y Biologia Molecular, Universidad del País Vasco (UPV/EHU), 48940, Leioa, Spain.

Received: 11 January 2013 Accepted: 13 March 2013

Published: 15 March 2013

\section{References}

1. Bonning BC, Miller WA: Dicistroviruses. Ann Rev Entomol 2010, 55:129-50.

2. Mayo MA: Virus taxonomy - Houston. Arch Virol 2002, 147:1071-1076.

3. Agirre J, Aloria K, Arizmendi JM, Iloro I, Elortza F, Sánchez-Eugenia R, Marti G, Neumann E, Rey FA, Guérin D: Capsid protein identification and analysis of mature Triatoma virus (TrV) virions and naturally occurring empty particles. Virology 2011, 409:91-101.

4. Chen IP, Siede R: Honey bee's viruses. Adv Virus Res 2007, 70:33-80.

5. Christian PD, Scotti PD: Picornalike viruses of insects. In The Insect Viruses. Edited by Miller LK, Ball LA. New York: Plenum; 1998.

6. Cox-Foster DL, Conlan S, Holmes EC, Palacios G, Evans JD, Moran NA, Quan $P L$, Briese $T$, Hornig $M$, et al: A metagenomic survey of microbes in honeybee colony collapse disorder. Science 2007, 318:283-87.

7. Wertheim JO, Tang KFJ, Navarro SA, Lightner DV: A quick fuse and emergence of Taura syndrome virus. Virology 2009, 390:324-29.

8. Cherry S, Silverman N: Host-pathogen interaction in drosophila: new tricks from an old friend. Nat Immunol 2006, 7:911-17.

9. Johnson KN, Christian PD: The novel genome organization of the insect picorna-like virus Drosophila $C$ virus suggests this virus belongs to a previously undescribed virus family. J Gen Virol 1998, 79:191-203.
10. Scotti PD, Longworth JF, Plus N, Croizier G, Reinganum C: The biology and ecology of strains of an insect small RNA virus complex. Adv Virus Res 1981, 26:117-43.

11. Moore NF, McKnight L, Tinsley TW: Occurrence of antibodies against insect virus proteins in mammals: simple model to differentiate between passive exposure and active virus growth. Infect Immun 1981, 31:825-827.

12. Muscio OA, Bonder MA, La Torre JL, Scodeller EA: Horizontal transmission of Triatoma Virus through the fecal-oral route in Triatoma infestans (Hemiptera:Triatominae). J Med Entomol 2000, 37:271-75.

13. Boyapalle S, Beckett RJ, Pal N, Miller WA, Bonning BC: Infectious genomic RNA of Rhophalosiphum padi virus transcribed in vitro from full-length cDNA clone. Virology 2008, 375:401-411.

14. Harrap KA: Assessment of the human and ecological hazard of microbial insecticides. Parasitology 1982, 84:269-296.

15. Manousis T, Moore NF: Cricket paralysis virus, a potential agent for the olive fruit fly, Dacus olea Gmel. Appl Environ Microbiol 1987, 53:142-148.

16. Muscio OA, La Torre JL, Bonder MA, Scodeller EA: Triatoma virus pathogenicity in laboratory colonies of Triatoma infestans (Hemiptera: Reduviidae). J Med Entomol 1997, 34:253-256.

17. Valles SM, Bextine B: Examination of host genome for the presence of integrated fragments of Solenopsis invicta virus 1. J Invert Pathol 2011, 107:212-215.

18. Coura JR, Viñas PA: Chagas disease: a new worldwide challenge. Nature 2010, 465:S6-S7.

19. World Health Organization: Chagas disease: control and elimination. Report of the Secretariat, EB124/17. Geneva: WHO; 2008.

20. Muscio OA, La Torre JL, Scodeller EA: Small noncluded viruses from bug Triatoma infestans (Hemiptera: Reduviidae). J Invert Pathol 1987, 49:218-220.

21. Estrozi LF, Neumann E, Squires G, Rozas-Dennis G, Costabel M, Rey FA, Guérin DMA, Navaza J: Phasing of the Triatoma virus diffraction data using a cryoelectron microscopy reconstruction. Virology 2008, 375:85-93.

22. Czibener C, La Torre JL, Muscio OA, Ugalde RA, Scodeller EA: Nucleotide sequence analysis of Triatoma virus shows that it is a member of a novel group of insect RNA viruses. J Gen Virol 2000, 81:1149-1154.

23. Susevich ML, Marti GA, Serena MS, Echeverría MG: New Triatoma virus hosts in wild habitats of Argentina. J Invertebr Pathol 2012, 110(3):405-7.

24. Squires G, Pous J, Agirre J, Rozas-Dennis GS, Costabel MD, Marti GA, Navaza J, Bressanelli S, Guérin DMA, Rey FA: Crystal structure of the Triatoma virus capsid. Acta Cryst D 2013. In press.

25. Marti GA, Echeverria MG, Susevich ML, Becnel JJ, Pelizza SA, García JJ: Prevalence and distribution of parasites and pathogens of Triatominae from Argentina, with emphasis on Triatoma infestans and Triatoma virus TrV. J Invert Pathol 2009, 102:233-237.

26. Marti GA, González ET, García JJ, Viguera AR, Guérin DM, Echeverría G: AC-ELISA and RT-PCR assays for the diagnosis of Triatoma virus (TrV) in triatomines (Hemiptera: Reduviidae) species. Arch Virol 2008, 153:1427-1432.

27. Rozas-Dennis GS, Cazzaniga NJ: Effect of Triatoma virus (TrV) on fecundity and molting in Triatoma infestans (Hemiptera: Reduviidae). Trop Med Parasitol 2000, 94:633-641.

28. Rozas-Dennis GS, Cazzaniga NJ, Guérin DM: Triatoma patagonica (Hemiptera: Reduviidae), a new host for Triatoma virus. Mem Inst Oswaldo Cruz 2002, 97:427-429.

29. Balkwill F: Cytokines, a pratical approach series. 2nd edition. New York: Oxford University Press; 1995

30. Stevens M, Hull R, Smith HG: Comparison of ELISA and RT-PCR for the detection of beet yellows closterovirus in plants and aphids. J Virol Method 1997, 68:9-16.

31. Nguyen L, Knipe DM, Finberg RW: Mechanism of virus-induced IgG subclass shifts. J Immunol 1994, 152:478-484.

32. Coutelier JP, van der Logt JTM, Heessen FWA, Vink A, Snick JV: Virally induced modulation of murine IgG antibody subclasses. J Exp Med 1988, 168:2373-2378.

doi:10.1186/1756-3305-6-66

Cite this article as: Querido et al:: Inoculation of Triatoma Virus

(Dicistroviridae: Cripavirus) elicits a non-infective immune response in mice. Parasites \& Vectors 2013 6:66. 